\title{
Differential Regulation of AMPA Receptor and GABA Receptor Trafficking by Tumor Necrosis Factor- $\alpha$
}

\author{
David Stellwagen, ${ }^{1}$ Eric C. Beattie ${ }^{2}$ Jae Y. Seo,${ }^{2}$ and Robert C. Malenka ${ }^{1}$ \\ ${ }^{1}$ Nancy Pritzker Laboratory, Department of Psychiatry and Behavioral Sciences, Stanford Medical School, Palo Alto, California 94305, and ${ }^{2}$ California Pacific \\ Medical Research Institute, San Francisco, California 94115
}

\begin{abstract}
The proinflammatory cytokine tumor necrosis factor- $\alpha(\mathrm{TNF} \alpha)$ causes a rapid exocytosis of AMPA receptors in hippocampal pyramidal cells and is constitutively required for the maintenance of normal surface expression of AMPA receptors. Here we demonstrate that TNF $\alpha$ acts on neuronal TNFR1 receptors to preferentially exocytose glutamate receptor 2-lacking AMPA receptors through a phosphatidylinositol 3 kinase-dependent process. This increases excitatory synaptic strength while changing the molecular stoichiometry of synaptic AMPA receptors. Conversely, TNF $\alpha$ causes an endocytosis of $\mathrm{GABA}_{\mathrm{A}}$ receptors, resulting in fewer surface $\mathrm{GABA}_{\mathrm{A}}$ receptors and a decrease in inhibitory synaptic strength. These results suggest that TNF $\alpha$ can regulate neuronal circuit homeostasis in a manner that may exacerbate excitotoxic damage resulting from neuronal insults.
\end{abstract}

Key words: GABA; receptor; synaptic; glutamate; trafficking; cytokine

\section{Introduction}

For many decades, the immune system and the CNS were thought to be independent of one another with minimal communication between them because the blood-brain barrier prevented immune cell infiltration into the parenchyma of the brain. It has become clear, however, that many immune molecules may be used constitutively by the CNS as signaling molecules involved in intercellular communication (Pan et al., 1997; Vitkovic et al., 2000; Perry et al., 2002; Golan et al., 2004). Furthermore, immune molecules such as cytokines are also thought to importantly contribute to the brain damage induced by a wide variety of neuronal insults as well as neurodegenerative diseases (New et al., 1998; Lock et al., 1999; Shohami et al., 1999; Nagatsu et al., 2000; Perry et al., 2001; Szelenyi, 2001), while also having some neuroprotective functions in certain circumstances (MorgantiKossmann et al., 2002; Stoll et al., 2002). Thus, elucidating the detailed mechanisms by which immune molecules affect neuronal function has important implications for understanding both normal brain function and the pathophysiology of a large number of neurological disorders.

One example of immune molecule influence on neuronal function can be seen in the regulation of synaptic transmission by cytokines. It is well established that glutamate is the main excitatory transmitter in the mammalian CNS and signals primarily through AMPA-type ionotropic glutamate receptors (AMPARs). Trafficking of these receptors is thought to underlie, at least in

Received Nov. 1, 2004; revised Jan. 10, 2005; accepted Feb. 17, 2005.

This work was supported by National Institutes of Health Grants MH63394 (R.C.M.) and MH065752 (D.S.). We thank E. Saura and D. Jhung for technical assistance, R. Huganir for kindly providing reagents, and W. Morishita, W. Ju, and X. Yu for helpful discussions.

Correspondence should be addressed to Robert Malenka, Department of Psychiatry and Behavioral Sciences, Stanford University, 1201 Welch Road, Room P105, Palo Alto, CA 94304-5485. E-mail: malenka@stanford.edu. DOI:10.1523/JNEUROSCI.4486-04.2005

Copyright $\odot 2005$ Society for Neuroscience $\quad$ 0270-6474/05/253219-10\$15.00/0 part, both rapid forms of synaptic plasticity and slower homeostatic changes in transmission (Malinow and Malenka, 2002; Turrigiano and Nelson, 2004). The surface expression of AMPARs appears to be tightly regulated in neurons, despite the constant cycling of receptors and rapid increases or decreases in response to stimulation. Recently, the proinflammatory cytokine tumor necrosis factor- $\alpha$ (TNF $\alpha$ ) was found to be a novel, gliareleased factor that increases the surface expression of AMPARs (Beattie et al., 2002). TNF $\alpha$ appeared to be constitutively released in both primary cell culture and acute hippocampal slices because blockade of TNF $\alpha$ signaling decreased the surface levels of AMPARs. These findings, as well as previous reports (Tancredi et al., 1992; Grassi et al., 1994; Emch et al., 2000), suggest that TNF $\alpha$ can have significant effects on neural circuit function. Furthermore, the TNF $\alpha$-induced increase in the surface expression of AMPARs may contribute significantly to its putative role in mediating the brain damage resulting from a variety of pathological insults (Gelbard et al., 1993; Chao and Hu, 1994; Le et al., 1997; Hermann et al., 2001).

Here we further investigate the synaptic effects of TNF $\alpha$ focusing on the following: (1) the receptor subtype and intracellular signaling cascade through which TNF $\alpha$ induces exocytosis of AMPARs, (2) TNF $\alpha$-induced changes in the stoichiometry of AMPARs, and (3) its effects on $\mathrm{GABA}_{\mathrm{A}}$ receptor surface expression and inhibitory synaptic transmission. The net effect of TNF $\alpha$ in both dissociated neuronal cultures and hippocampal slices was to change the balance of excitatory and inhibitory synaptic transmission in a manner that should greatly exacerbate the excitotoxicity induced by neuronal insults that increase TNF $\alpha$ levels and/or signaling.

\section{Materials and Methods}

Immunostaining. Postnatal hippocampal cultures were prepared as described previously (Beattie et al., 2000). Banker-style cultures were pre- 
pared as described previously (Goslin et al., 1998). Surface AMPARs were visualized in 15- to 25-d-old cultures after treatment with vehicle or 60 nM TNF $\alpha$ for $15-20 \mathrm{~min}$ at $37^{\circ} \mathrm{C}$. After treatment, cells were chilled on ice, washed with cold PBS, and fixed with $4 \%$ paraformaldehyde. The nonpermeabilized cells were then blocked with $3 \%$ bovine serum albumin and 2\% normal goat serum in PBS and a rabbit antibody directed at the $\mathrm{N}$ terminus of glutamate receptor 1 (GluR1) (gift from R. Huganir, Johns Hopkins University School of Medicine, Baltimore, MD) was applied at a dilution of 1:1000 for $1 \mathrm{~h}$. Cells were sometimes costained with N-terminal antibodies against GluR2 (1:200; Chemicon, Temecula, CA) or the $\mathrm{GABA}_{\mathrm{A}} \beta 2 / 3$ subunit (1:300, MAB341; Chemicon). An anti-rabbit secondary antibody (Alexa 568; Alexis Biochemicals, San Diego, CA) was applied at a dilution of 1:1000. Anti-mouse Alexa 488 secondary was added in double-labeling experiments. Endocytosed receptors were visualized by adding antibodies to live cells for $30 \mathrm{~min}$ and then treating cells for an additional $15 \mathrm{~min}$ with TNF $\alpha$. Cells were then chilled, stripped of remaining surface antibodies with a 3 min treatment of $0.5 \mathrm{M} \mathrm{NaCl}$ and $0.2 \mathrm{M}$ acetic acid solution, fixed in paraformaldehyde, permeabilized with $0.1 \%$ Triton-X, and labeled with secondary antibodies. Labeled cells were imaged using a $63 \times$ objective mounted on a Zeiss (Oberkochen, Germany) Axioskop. Images were obtained using a cooled CCD camera (Hamamatsu, Bridgewater, NJ) and were analyzed using MetaMorph software (Universal Imaging Corporation, West Chester, PA). For individual experiments, images for all conditions were analyzed using identical acquisition parameters, and untreated and treated cells from the same culture preparation were always compared with one another. The images were also collected blind to the experimental condition. The total thresholded area of fluorescently labeled, surface AMPARs was measured automatically by the MetaMorph software and divided by the total cell area, which was determined by setting a lower threshold level to measure background fluorescence produced by the fixed cells. For each experiment, the fluorescence of all cells was normalized by dividing by the average fluorescence of the untreated control cells. Each experimental manipulation was repeated a minimum of three times using different culture preparations. Fixation by paraformaldehyde did not permeabilize the cells, as judged by microtubule-associated protein 2 (MAP2) staining. However, because of variation in the quality of B-27 supplement and possibly other issues of culture health, not all culture preparations were responsive to TNF $\alpha$. Therefore, all experiments included a positive control of TNF $\alpha$ treatment, and culture preparations that failed to respond to TNF $\alpha$ with a $>40 \%$ increase in GluR1 surface staining ( $\sim 20 \%$ of total) were excluded from analysis. $n$ values in the text represent the number of microscope fields examined. Statistical significance was determined using Student's $t$ test. Error bars in figures represent SEM.

Cell surface biotinylation. Determination of the amount of AMPAR subunit surface expression was accomplished using a procedure modified from previous studies (Tsao and von Zastrow, 2000). Briefly, hippocampal cultures were prepared exactly as described for immunofluorescence, with the exception of the final plating procedure; for biochemical analysis, neurons were plated on poly-D-lysine-coated sixwell plates and cultured for 3-3.5 weeks before subunit surface expression analysis. TNF $\alpha$ at $60 \mathrm{nM}$ or vehicle was given to neurons for $15 \mathrm{~min}$ at $37^{\circ} \mathrm{C}$, and neurons were chilled on ice and washed twice with cold PBS. PBS at $1 \mathrm{ml}$ containing $1 \mathrm{mg} / \mathrm{ml}$ disulfide $\mathrm{N}$-hydroxysuccininmide ester biotin (catalog \#B4531; Pierce, Rockford, IL) was then added to each well. Neurons were incubated at $4^{\circ} \mathrm{C}$ for $30 \mathrm{~min}$ with gentle rocking. The reaction was stopped by washing the neurons three times for $10 \mathrm{~min}$ each with chilled Tris-buffered saline or $0.1 \mathrm{M}$ glycine in PBS. Radioimmunoprecipitation assay (RIPA) lysis buffer $(1 \mathrm{ml})$ with a protease inhibitor mixture (catalog \#539131; Calbiochem, La Jolla, CA) was used to harvest neurons from three individual wells by cell scraper. This amount of cell material was used for each experimental condition, was subsequently allowed to rotate at $4^{\circ} \mathrm{C}$ for $30 \mathrm{~min}$, and then was spun out in a tabletop microcentrifuge for $10 \mathrm{~min}$ at $10,000 \mathrm{rpm}$. Lysate $(50 \mu \mathrm{l})$ was removed to be run on a Bradford protein concentration assay to ensure that samples of the experimental conditions represented the same amount of total protein. The supernatant was immunoprecipitated with streptavidin beads (catalog \#20349; Pierce) overnight at $4^{\circ} \mathrm{C}$ with rotation. Beads were washed with RIPA buffer, eluted in SDS sample buffer, run out using PAGE, and transferred to nitrocellulose; the resulting Western blot was probed for GluR1 or GluR2 with antibodies from Chemicon (GluR1, catalog \#AB1504; GluR2, catalog \#MAB397). Signal was detected by the use of ECL and BioMax film (Eastman Kodak, Rochester, NY). Band intensities were quantified by ImageQuant Analysis program (Molecular Dynamics, Sunnyvale, CA). $n$ values for these experiments represents number of separate culture preparations tested.

Culture electrophysiology. Recordings of miniature EPSCs (mEPSCs) were made from 15- to 24-d-old cultures essentially as described previously (Beattie et al., 2000). Briefly, whole-cell patch-clamp recordings were made with an Axopatch 1D amplifier (Axon Instruments, Union City, CA). Pipette solutions contained the following (in mM): 122 Csgluconate, $8 \mathrm{NaCl}, 10$ glucose, $1 \mathrm{CaCl}_{2}, 10$ HEPES, 10 EGTA, $0.3 \mathrm{Na}_{3}$ GTP, and $2 \mathrm{Mg}$-ATP, pH 7.2. Cultures were superfused with normal Ringer's solution (in mM: $115 \mathrm{NaCl}, 5 \mathrm{KCl}, 23$ glucose, 26 sucrose, 4.2 HEPES, $2.5 \mathrm{CaCl}_{2}$, and $1.3 \mathrm{MgCl}_{2}, \mathrm{pH} 7.2$ ) containing $200 \mathrm{~nm}$ tetrodotoxin, $50 \mu \mathrm{M}$ picrotoxin, and $50 \mu \mathrm{M}$ D-APV. Data were acquired at $2 \mathrm{kHz}$ with Igor Pro software (WaveMetrics, Lake Oswego, OR) and analyzed with Mini Analysis software (Synaptosoft, Decatur, GA). All mEPSCs above a threshold value set for each cell (5-6 pA) were included in the data analysis, and each mEPSC was verified visually. TNF $\alpha$ (60 nM) was applied to cultures 15-25 min before recording and compared with untreated sister cultures. $N$-(4-hydroxyphenylpropanoyl) (HPP)-spermine (10 $\mu \mathrm{M}$; Tocris Cookson, Ballwin, MO) was bath applied.

Slice electrophysiology. Transverse hippocampal slices $(400 \mu \mathrm{m})$ were prepared from 2- to 4-week-old Sprague Dawley rats as described previously (Luscher et al., 1999). Slices were incubated in the external perfusing medium containing the following (in $\mathrm{mM}$ ): $119 \mathrm{NaCl}, 2.5 \mathrm{KCl}, 2.5$ $\mathrm{CaCl}_{2}, 1.3 \mathrm{MgSO}_{4}, 1 \mathrm{NaH}_{2} \mathrm{PO}_{4}, 26.2 \mathrm{NaHCO}_{3}, 11$ glucose, and 0.05 picrotoxin (saturated with $95 \% \mathrm{O}_{2} / 5 \% \mathrm{CO}_{2}$ ). To examine the effects of $\mathrm{TNF} \alpha$, slices were incubated in external solution containing $600 \mathrm{~nm}$ $\mathrm{TNF} \alpha$ for a minimum of $2-3 \mathrm{~h}$ before experiments commenced. Throughout each experimental day, recordings from control and TNF $\alpha$ treated slices prepared from the same animal were interleaved. Slices were transferred to a submersion-type recording chamber mounted on an Zeiss Axioskop microscope equipped with infrared-differential interference contrast optics and were continually perfused with perfusing medium at room temperature $\left(2 \mathrm{ml} / \mathrm{min}, 22-23^{\circ} \mathrm{C}\right)$. Whole-cell voltageclamp or current-clamp recordings were made from CA1 pyramidal cells with an Axopatch 1D amplifier (Axon Instruments). The whole-cell recording solution contained the following (in mM): 120 Cs-gluconate, 10 HEPES, 10 EGTA, $15.5 \mathrm{CsCl}, 8 \mathrm{NaCl}, 2 \mathrm{MgATP}$, and 0.3 GTP, pH 7.3. In some experiments, Cs-gluconate was replaced with $\mathrm{CsCl}$ (for mIPSCs) or $\mathrm{KMeSO}_{4}$ (for compound postsynaptic potentials). Postsynaptic potentials were evoked by stimulating Schaffer collaterals at a frequency of 0.1 or $0.05 \mathrm{~Hz}$ with a glass pipette filled with external solution. Miniature EPSCs and IPSCs were recorded from cells clamped at $-70 \mathrm{mV}$ in the presence of $1 \mu \mathrm{M}$ TTX and $50 \mu \mathrm{M}$ D-APV plus 2,3-dihydroxy-6-nitro-7sulfonyl-benzo[f]quinoxaline (for mIPSCs) or picrotoxin (PTX) (for mEPSCs). Analysis of mPSCs was performed using Mini Analysis 5 software (Synaptosoft). Each mPSC included in the final data analyses was verified visually. Compound postsynaptic potentials were recorded in current clamp, in the presence of $2 \mu \mathrm{M}$ of the $\mathrm{GABA}_{\mathrm{B}}$ antagonist CGP 55845 and omitting PTX. The amplitude of the EPSP and IPSP were compared from the averaged responses to three to four stimulation intensities per cell. Group results were compared using Student's $t$ test, and mPSC cumulative distributions were compared using a KolmogorovSmirnov two sample test.

Drug treatments. All drugs were bath applied in culture media at $37^{\circ} \mathrm{C}$ in the incubator, unless otherwise noted. Cultures were treated for 15-25 min with TNF $\alpha$ (60 nM), interleukin-1 $\beta$ (IL-1 $\beta)$ (50 ng/ml), IL-6 (32 $\mathrm{ng} / \mathrm{ml})$, IL-10 $(40 \mathrm{ng} / \mathrm{ml})$, or activating antibodies for TNFR1 $(2 \mu \mathrm{g} / \mathrm{ml})$ or TNFR2 $(2 \mu \mathrm{g} / \mathrm{ml})$ and immediately either processed for immunocytochemistry or used for electrophysiology. Inhibitors of protein kinase A (PKA) (PKI, $1 \mu \mathrm{M})$, calcium/calmodulin-dependent protein kinase II (CaMKII) (KN-93, $20 \mu \mathrm{M})$, cyclooxygenase-2 (COX-2) (aspirin, $10 \mu \mathrm{M}$ ), p38 MAP kinase (SB 203580, $50 \mu \mathrm{M}$ ), p42-44 MAP kinase (PD 98059, 50 $\mu \mathrm{M}$ ), and phosphatidylinositol 3 kinase (PI3K) (wortmannin, $100 \mathrm{nM}$; 

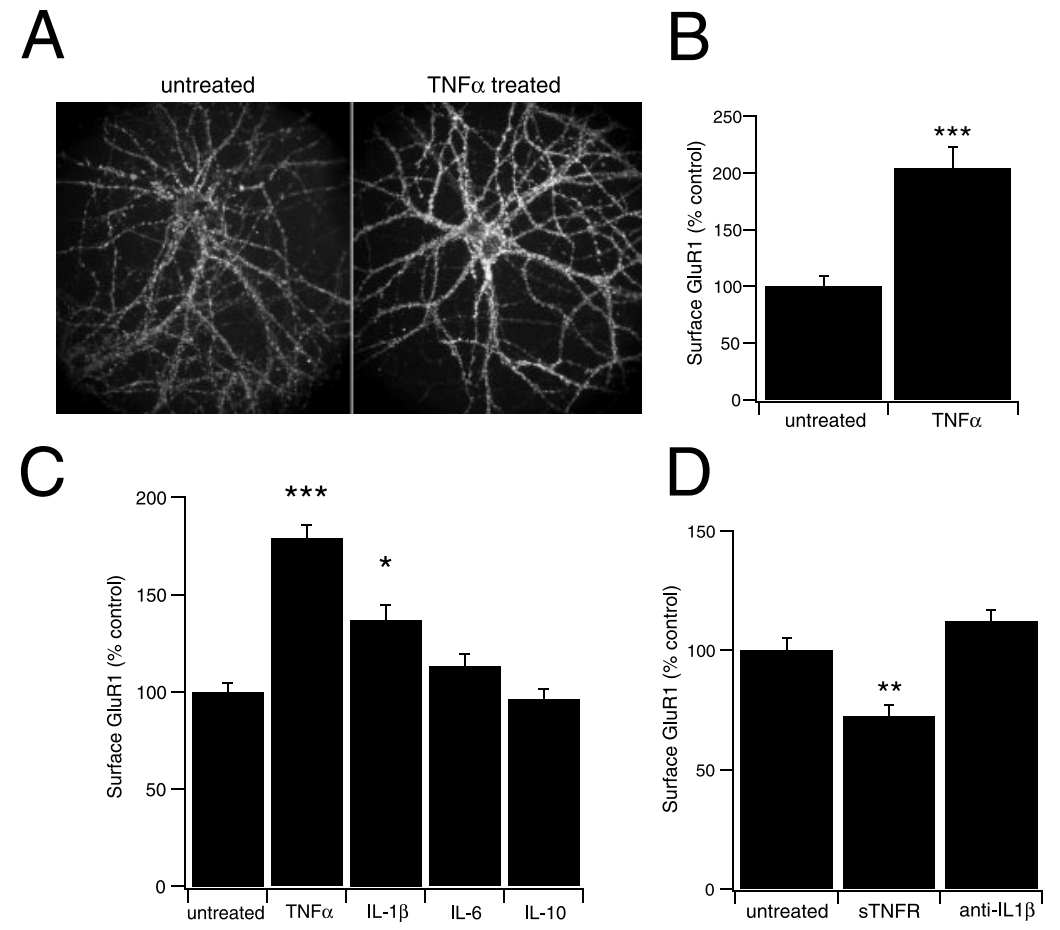

Figure 1. TNF $\alpha$, unlike other cytokines, acts on neurons to increase surface expression of AMPARs. $A$, Representative micrographs from sister cultures of nonpermeabilized isolated neurons immunostained for surface expression of the AMPA subunit GluR1. The cells on the right were treated with $60 \mathrm{~nm}$ TNF $\alpha$ for $15 \mathrm{~min}$. B, Group data from untreated or TNF $\alpha$-treated cultures $(n=70$ for both conditions), showing a substantial increase in surface GluR1 staining. $C$, Composite data of surface GluR1 from cultures treated with TNF $\alpha$ $(60 \mathrm{~nm} ; n=214), \mathrm{IL}-1 \beta(50 \mathrm{ng} / \mathrm{ml} ; n=140), \mathrm{IL}-6(32 \mathrm{ng} / \mathrm{ml} ; n=159)$, or IL-10 $(40 \mathrm{ng} / \mathrm{ml} ; n=130) . D$, Group data of surface GluR1 from cultures treated for $24 \mathrm{~h}$ with sTNFR $(10 \mu \mathrm{g} / \mathrm{ml} ; n=59)$ or an antibody against IL-1 $\beta(40 \mu \mathrm{g} / \mathrm{ml} ; n=72)$. For this and all subsequent figures, ${ }^{*} p<0.05 ;{ }^{* *} p<0.001 ;{ }^{* * *} p<0.0001$ when compared with untreated cultures.
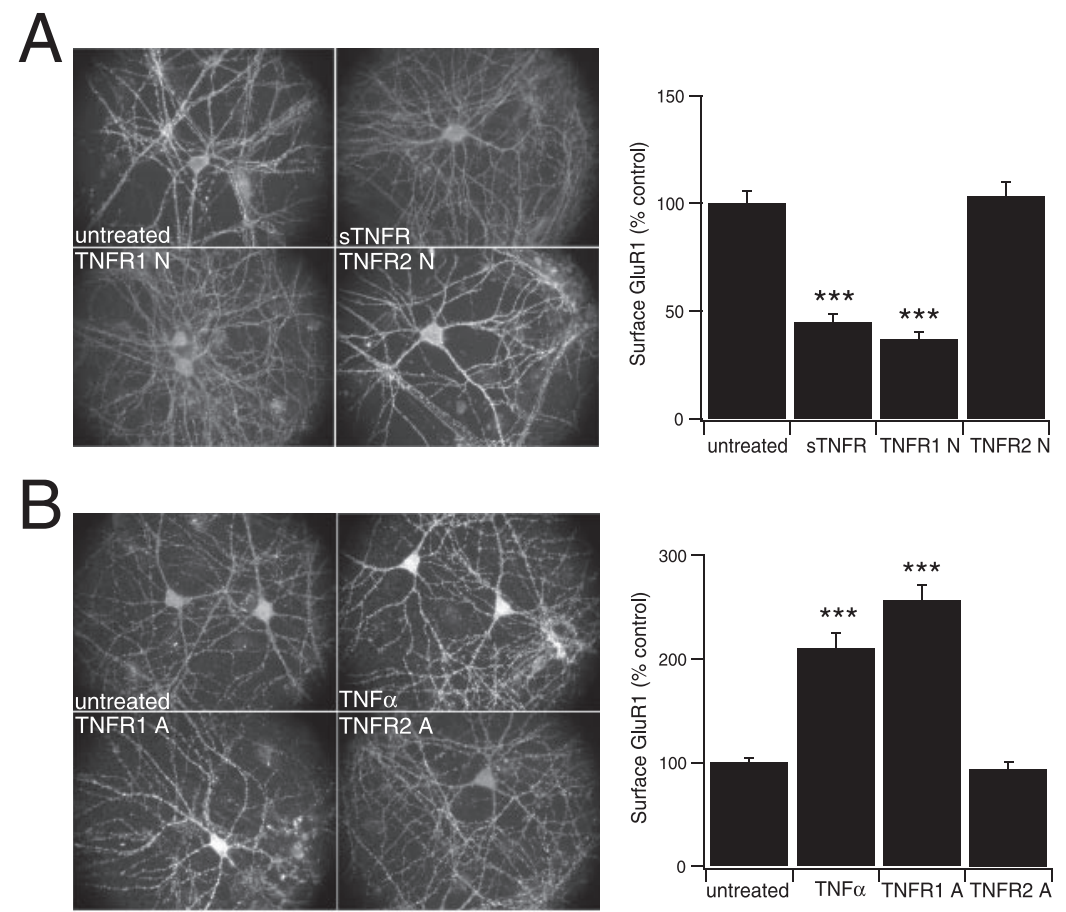

Figure 2. TNF $\alpha$ acts via TNFR1 to increase surface AMPARs. A, Representative micrographs and composite data from cultures treated for $24 \mathrm{~h}$ with sTNFR ( $10 \mu \mathrm{g} / \mathrm{ml} ; n=54)$, which decreased the surface expression of GluR1 relative to untreated control cells. Treatment for $24 \mathrm{~h}$ with a neutralizing antibody for TNFR1 (TNFR1 N; $5 \mu \mathrm{g} / \mathrm{ml} ; n=66$ ) also causes a similar decrease in GluR1 surface expression. Neutralizing antibodies for TNFR2 (TNFR2 N; $15 \mu \mathrm{g} / \mathrm{ml} ; n=84$ ) were ineffective at decreasing GluR1 surface expression. B, Sample micrographs and composite data demonstrating that an activating antibody for TNFR1 (TNFR1 A; $2 \mu \mathrm{g} / \mathrm{ml}$; $n=81)$ increases the surface expression of GluR1 to a similar degree as sister cultures treated with $\operatorname{TNF} \alpha(n=69)$, whereas an activating antibody for TNFR2 (TNFR2 $\mathrm{A} ; 2 \mu \mathrm{g} / \mathrm{ml} ; n=88$ ) was ineffective at increasing surface GluR1. and LY 294,002, $50 \mu \mathrm{M}$ ) were applied to cultures for $2 \mathrm{~h}$ before TNF $\alpha$ application. Receptorneutralizing antibodies (TNFR1 N, $5 \mu \mathrm{g} / \mathrm{ml}$; TNFR2 $\mathrm{N}, 15 \mu \mathrm{g} / \mathrm{ml})$, soluble TNF receptors (sTNFRs) $(10 \mu \mathrm{g} / \mathrm{ml})$, or antibodies against IL-1 $\beta(40 \mu \mathrm{g} / \mathrm{ml})$ were applied for $24 \mathrm{~h}$. HPPspermine $(10 \mu \mathrm{M})$ was bath applied in culture external solution in the electrophysiology recording chamber. Cytokines and cytokine receptor materials were from $\mathrm{R} \& \mathrm{D}$ Systems (Minneapolis, MN), except the TNFR2 activating antibodies, which were from Abcam (Cambridge, MA). Inhibitors were purchased from Tocris Cookson.

\section{Results}

TNF $\boldsymbol{\alpha}$ increases surface AMPARs via activation of neuronal TNFR1

Our previous experiments on TNF $\alpha$ (Beattie et al., 2002) used mixed neuronal-glial cell cultures, and therefore we could not determine whether TNF $\alpha$ was acting directly on the neurons to cause the exocytosis of AMPARs or was inducing glia to release another factor that then acted on the neurons (Bezzi et al., 2001). To address this issue, we removed "Banker cultures" (Goslin et al., 1998) from their glial feeder layers, treated the isolated neurons with $\mathrm{TNF} \alpha$ (60 $\mathrm{nM}, 15 \mathrm{~min}$ ), and then assayed the surface expression of AMPARs using an N-terminal antibody to GluR1 on nonpermeabilized cells (Fig. 1). TNF $\alpha$ induced a robust increase in the surface expression of AMPARs $(204 \pm 18 \%$ of untreated cultures; $n=70$ ) (Fig. $1 B$ ), an increase indistinguishable from that seen in mixed neuronal-glial cultures (Beattie et al., 2002). This result indicates that the increase in surface expression of AMPARs is attributable to the direct action of TNF $\alpha$ on neurons and not through another cell type.

Several findings suggest that the increase in AMPAR surface expression is relatively specific to TNF $\alpha$ and is not a general effect of cytokines on neurons. A second proinflammatory cytokine, IL- $1 \beta$ (50 ng/ml), induced a smaller although significant increase in AMPAR surface expression (137 $\pm 8 \%$ of untreated cultures; $n=140 ; p<0.015$ ) (Fig. $1 C$ ). However, IL- $1 \beta$ does not appear to be constitutively released in our cultures, because treating cultures for $24 \mathrm{~h}$ with anti-IL- $1 \beta$ antibodies did not alter the surface expression of AMPARs $(40 \mu \mathrm{g} / \mathrm{ml} ; 112 \pm 5 \% ; n=72)$ (Fig. 1D). In contrast, consistent with our previous results (Beattie et al., 2002), a recombinant soluble form of the TNF $\alpha$ receptor TNFR1 (sTNFR), which binds endogenous TNF $\alpha$ (Bezzi et al., 2001), decreased surface GluR1 staining $(10 \mu \mathrm{g} /$ $\mathrm{ml} ; 72 \pm 5 \% ; n=59$ ) (Fig. 1D). A third proinflammatory cytokine, IL-6, induced, 
on average, no significant increase in surface AMPAR levels $(32 \mathrm{ng} / \mathrm{ml} ; 111 \pm 6 \%$ of untreated cultures; $n=159)$, whereas the anti-inflammatory cytokine IL-10 had no effect on surface AMPARs ( $40 \mathrm{ng} / \mathrm{ml}$; $96 \pm$ $5 \% ; n=130$ ) (Fig. 1C). These data suggest that, among these cytokines, TNF $\alpha$ alone is used constitutively by the nervous system to regulate the surface expression of AMPARs.

Hippocampal neurons express both forms of TNF $\alpha$ receptor, TNFR1 and TNFR2 (Neumann et al., 2002; Yang et al., 2002). Although the receptors share several of the same downstream signaling cascades, they each also have some unique signaling characteristics, including the presence of a death domain on TNFR1 (Tartaglia et al., 1991; Rath and Aggarwal, 1999; Baud and Karin, 2001). To determine which subtype of TNF $\alpha$ receptor was responsible for the increase in AMPAR surface expression, we examined the effects of neutralizing antibodies for the individual receptors on endogenous $\mathrm{TNF} \alpha$ signaling and again compared this with the effects of sequestering TNF $\alpha$ with sTNFR. As expected, incubating these sets of cultures for $24 \mathrm{~h}$ with sTNFR significantly reduced the surface expression of AMPARs $(45 \pm 4 \%$ of untreated cells; $n=54)$ (Fig. $2 A)$, a finding that demonstrates that endogenous TNF $\alpha$ is present in these cultures and influences AMPAR surface expression. Antibodies that block signaling through TNFR1 caused a similar reduction of surface AMPARs after $24 \mathrm{~h}(37 \pm 3 \%$ of untreated cells; $n=66)$, whereas the same treatment with antibodies that block signaling through TNFR2 did not decrease the surface levels of AMPARs ( $103 \pm 7 \%$ of untreated cells; $n=84$ ). Consistent with a primary role for TNFR1 in mediating the effects of TNF $\alpha$ on AMPARs, stimulation of TNFR1 alone using an activating antibody for 15 min (Diem et al., 2001) caused a clear increase in the surface expression of AMPARs ( $257 \pm 15 \%$ of untreated cells; $n=81$ ) (Fig. $2 B$ ), on par with the upregulation seen in sister cultures treated with TNF $\alpha(210 \pm 15 \% ; n=69)$. TNFR2 activating antibodies, in contrast, were ineffective at increasing the surface expression of AMPARs ( $94 \pm 7 \%$ of untreated cells; $n=88$ ) (Fig. $2 B)$. These results demonstrate that activation of TNFR1 is necessary for the maintenance of surface expression of AMPARs and is sufficient for their rapid exocytosis.

TNFR1 initiates signaling through an array of downstream pathways, most known for their roles in gene expression and apoptosis (Pan et al., 1997; Baud and Karin, 2001). Because we were studying rapid trafficking events, we concentrated on enzymes and protein kinases that have been reported to be activated by $\mathrm{TNF} \alpha$ and also are thought to be involved with various forms of exocytosis. Incubation of cultures with inhibitors of CaMKII, cAMP-dependent PKA, p38 MAP kinase, p42-44 MAP kinase, and COX did not prevent the normal increase in surface expression of AMPARs induced by TNF $\alpha$ treatment (Fig. 3A), suggesting that these enzymes are not required for this action of TNF $\alpha$. However, in contrast, two structurally distinct inhibitors of PI3K, wortmannin and LY 294,002, each completely prevented the
TNF $\alpha$-induced increase in surface levels of AMPARs (Fig. $3 B, C$ ) Specifically, TNF $\alpha$ application to cultures pretreated with wortmannin or LY 294,002 had surface AMPAR levels indistinguishable from pretreated cultures not given TNF $\alpha$ (wortmannin plus TNF $\alpha, 111 \pm 6 \%$ of wortmannin alone, $n=272$; LY 294,002 plus TNF $\alpha, 88 \pm 10 \%$ of LY 294,002 alone, $n=60 ; p>0.27)$. Pretreatment with wortmannin or LY 294,002 did not in itself significantly alter the surface expression of GluR1 (data not shown). Thus, similar to the actions of insulin and glycine on cultured neurons (Passafaro et al., 2001; Man et al., 2003), the increase in AMPAR surface expression attributable to TNF $\alpha$ appears to require PI3K activity.

\section{TNF $\alpha$ preferentially increases synaptic expression of GluR2-lacking AMPARs}

Endogenous AMPARs in hippocampal pyramidal cells are thought to be heteromultimers, with GluR1 normally forming receptors in conjunction with GluR2 (Wenthold et al., 1996). The presence of edited GluR2 makes the AMPARs relatively impermeable to $\mathrm{Ca}^{2+}$ and insensitive to block by polyamines such as spermine (Washburn et al., 1997; Mainen et al., 1998; Dingledine et al., 1999). Our measurements of surface AMPARs thus far depend solely on tracking the GluR1 subunit of endogenous AMPARs. Because recent results suggest that increases in synaptic strength as a result of homeostatic synaptic scaling (Turrigiano and Nelson, 2004) involve increased synaptic expression of GluR2-lacking AMPARs (Thiagarajan et al., 2003; Ju et al., 2004), it was of interest to examine whether TNF $\alpha$ also increased the surface expression of GluR2. Surprisingly, although TNF $\alpha$ induced a robust twofold increase in GluR1 surface expression, in 

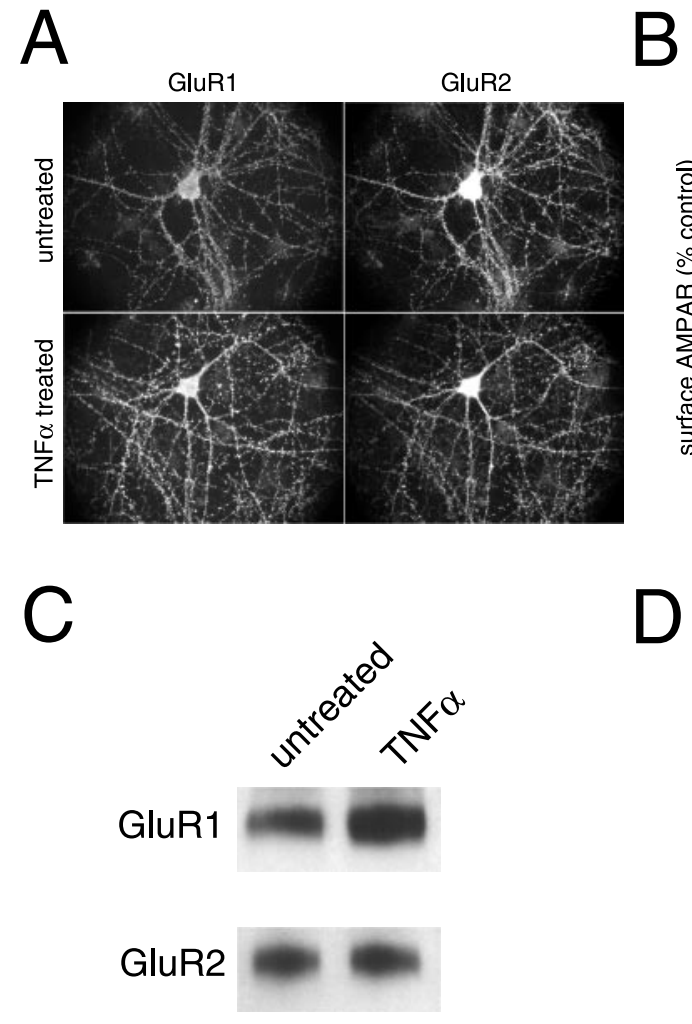

12) (Fig. 5B) and a leftward shift of the cumulative amplitude distribution (Fig. $5 C)$. Furthermore, whereas the mean mEPSC amplitude (untreated, $14.9 \pm 1.5$ $\mathrm{nA}, 13$ cells; TNF $\alpha, 20.2 \pm 2.1 \mathrm{nA}, 15$ cells; $p<0.05$ ) (Fig. 5D) and cumulative mEPSC amplitude distribution (Fig. 5E) before HPP-spermine application was significantly different between TNF $\alpha$-treated and untreated cells $(p<0.0012)$, the postHPP-spermine mean amplitude and cumulative distributions were not significantly different $(p>0.5)$. These results suggest that TNF $\alpha$ caused a significant increase in the proportion of GluR2-lacking AMPARs at synapses.

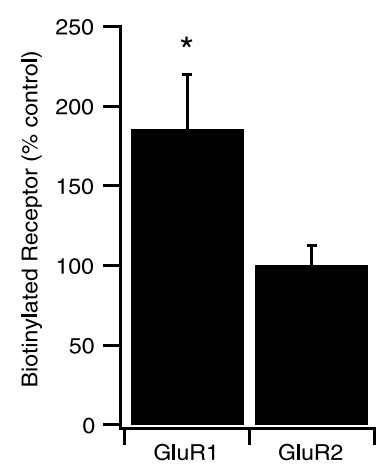

Figure 4. TNF $\alpha$ does not increase the surface expression of GluR2. A, Representative micrographs from cultured neurons double labeled for surface GluR1 and GluR2, after treatment with TNF $\alpha$. Despite a clear increase in GluR1 surface expression, GluR2 surface levels are not increased relative to untreated cultures. $\boldsymbol{B}$, Quantification of all doubled-labeled cells, showing a significant increase in GluR1 surface expression after TNF $\alpha$ treatment (black bars; $n=177$ ) compared with untreated cells (gray bars; $n=$ 156), whereas the same cells had no significant increase in GluR2 surface expression relative to untreated controls. C, Representative blots from surface biotinylation experiments from sister cultures, probed for GluR1 or GluR2, after treatment with TNF $\alpha$. D, Quantification of all experiments for the levels of biotinylated receptors ( $n=7$ cultures for GluR1, 6 for GluR2).

the same cells, it caused no significant increase in GluR2 surface expression $(110 \pm 5 \% ; n=177)$ (Fig. $4 A, B)$. It is possible that the antibodies to GluR1 might somehow sterically inhibit antibody staining of surface GluR2, and, therefore, we used an alternative technique, biotinylation of surface AMPARs (Ehlers, 2000; Kim and von Zastrow, 2003), to reexamine whether GluR2 surface expression was increased by TNF $\alpha$. Consistent with the immunostaining results, TNF $\alpha$ caused a clear increase in surface biotinylated GluR1 ( $185 \pm 35 \%$ of untreated cultures; $n=9)$ but no increase of surface GluR2 (100 $\pm 13 \%)$ (Fig. 4C,D).

These results suggest that many, if not most, of the new surface AMPARs lack the GluR2 subunit, resulting in receptors that are calcium permeable, inwardly rectifying, and inhibited by polyamines such as HPP-spermine (Washburn et al., 1997; Mainen et al., 1998; Dingledine et al., 1999). To directly test whether, after TNF $\alpha$ treatment, the properties of synaptic AMPARs had changed in a manner consistent with the previous results, we recorded mEPSCs and examined the effects of HPP-spermine. Consistent with previous results (Ju et al., 2004), cells from control cultures showed no sensitivity to HPP-spermine, with the mEPSC amplitude remaining unchanged after bath application of HPP-spermine ( $10 \mu \mathrm{M} ; 100 \pm 3 \%$ of initial mEPSC amplitude; $n=10$ ) (Fig. 5A-C). In contrast, HPP-spermine caused a reduction in mEPSC amplitude in cells treated for $20 \mathrm{~min}$ with TNF $\alpha$ (Fig. 5A-C). This was evident in both the measurements of mean mEPSC amplitude $(82.7 \pm 2.4 \%$ of initial mEPSC amplitude; $n=$ $\beta 1$ has negligible expression in the hippocampus (Persohn et al., 1992; Sperk et al., 1997). Using an antibody to the $\mathrm{GABA}_{\mathrm{A}}$ receptor $\beta 2 / 3$ subunit (Richards et al., 1987), there was no increase in the level of surface expression of $\mathrm{GABA}_{\mathrm{A}}$ receptors after $15 \mathrm{~min}$ of $\mathrm{TNF} \alpha$ treatment compared with untreated cultures, despite a nearly twofold increase in the surface AMPARs that were measured in the same cells (Fig. 6A). In fact, TNF $\alpha$ caused a small but significant reduction in $\mathrm{GABA}_{\mathrm{A}}$ receptor surface expression $(88 \pm 4 \% ; n=237 ; p<0.01)$.

A reduction in surface levels of $\mathrm{GABA}_{\mathrm{A}}$ receptors is most likely attributable to an increase in endocytosis of the receptors. We tested this prediction by labeling surface $\mathrm{GABA}_{\mathrm{A}}$ receptors in live cells, treating the cells with TNF $\alpha$, allowing endocytosis to occur, stripping the antibody off the remaining surface receptors, and then immunostaining the internalized receptors (for details, see Materials and Methods). Treatment with TNF $\alpha$ nearly doubled the amount of internalized $\mathrm{GABA}_{\mathrm{A}}$ receptors compared with untreated control cells (196 $\pm 17 \% ; n=55)$ (Fig. $6 B$ ) but had no effect on the amount of endocytosed AMPARs. The amount of constitutive endocytosis of $\mathrm{GABA}_{\mathrm{A}}$ receptors is much lower than for AMPARs (data not shown), so that a large proportional increase in the amount of endocytosed $\mathrm{GABA}_{\mathrm{A}}$ receptors would still only be equivalent to a modest proportion of the total number of surface receptors. Together, these data suggest that TNF $\alpha$ decreases the levels of surface $\mathrm{GABA}_{\mathrm{A}}$ receptors while simultaneously increasing surface AMPAR levels.

To test whether the effects of TNF $\alpha$ on AMPAR and GABA 
receptor trafficking in cultured neurons occurred in more intact preparations and had the predicted effects on excitatory and inhibitory synaptic transmission, we recorded mEPSCs and mIPSCs from acute hippocampal slices pretreated with TNF $\alpha$. Incubation of slices in TNF $\alpha$ caused an increase in the mean amplitude of mEPSCs $(125 \pm 7 \%$ of control; $n=10,12)$ (Fig. $7 A)$ and a rightward shift in the cumulative distribution of mEPSC amplitudes. In contrast, the mean amplitude of mIPSCs was decreased in $\mathrm{TNF} \alpha$-treated slices $(86 \pm 5 \%$ of control; $n=7,8)($ Fig. $7 B)$ when compared with control slices and, there was a significant leftward shift in the cumulative amplitude distribution (Fig. $7 B$ ). (Changes in the frequency of mEPSCs and mIPSCs were in the expected directions but did not reach statistical significance.)

Modest increases in mEPSC amplitude combined with small decreases in mIPSC amplitude could combine to result in much larger changes in the ratio of excitatory to inhibitory synaptic transmission and thereby significantly affect network properties. To test this prediction, we evoked compound postsynaptic potentials consisting of an initial EPSP followed by a $\mathrm{GABA}_{\mathrm{A}}$ receptor-mediated IPSP (recordings were made in the presence of a $G_{A B A}$ receptor antagonist to isolate the $\mathrm{GABA}_{\mathrm{A}}$ component of the IPSP). The ratio of EPSP to IPSP amplitude from acute slices incubated in TNF $\alpha$ was increased more than twofold when compared with untreated slices from the same animal (EPSP/IPSP ratio, TNF $\alpha$ treated cells, $7.4 \pm 1.4, n=11$; untreated cells, $3.1 \pm 0.8, n=10$ ) (Fig.

7C). Together, these data indicate that treatment with TNF $\alpha$ can substantially influence the relative contribution of excitatory and inhibitory synaptic transmission and presumably have a significant effect on neural circuit behavior.

\section{Discussion}

TNF $\alpha$ is a proinflammatory cytokine that has been implicated in playing an important role in the neuronal damage caused by a variety of brain insults, such as stroke and head trauma, as well as that which occurs during neurodegenerative disorders (New et al., 1998; Lock et al., 1999; Shohami et al., 1999; Nagatsu et al., 2000; Perry et al., 2001; Szelenyi, 2001). In addition, there is evidence that it also plays an important role in normal neural circuit development and function (Pan et al., 1997; Vitkovic et al., 2000; Beattie et al., 2002; Neumann et al., 2002; Perry et al., 2002; Golan et al., 2004). Here we focused on the synaptic effects of TNF $\alpha$, specifically on its effects on AMPAR and GABA receptor trafficking and the consequences for excitatory and inhibitory synaptic transmission. We show that $\mathrm{TNF} \alpha$, acting on neuronal TNFR1 receptors, increases surface AMPARs through a PI3 kinase-dependent pathway. Many of the newly exocytosed AMPARs lacked or had lower stoichiometric amounts of GluR2, as evidenced by their sensitivity to HPP-spermine (Washburn et al.,
1997; Dingledine et al., 1999). This change in the stoichiometry of synaptic AMPARs presumably will make at least some proportion of the receptors $\mathrm{Ca}^{2+}$ permeable. Surprisingly, we found that TNF $\alpha$ also simultaneously decreased surface $\mathrm{GABA}_{\mathrm{A}}$ receptors, resulting in a decrease in inhibitory synaptic transmission. Thus, the net effect of TNF $\alpha$ was to alter the balance of excitation and inhibition in a manner, to our knowledge, unlike previously studied neuromodulators.

We note that we observed amplitude changes in mEPSCs in both culture and slices after TNF $\alpha$ treatment, whereas in our previous paper (Beattie et al., 2002), we primarily observed a change in mEPSC frequency. This apparent discrepancy probably arises from the different recording techniques used in the two papers. The previous technique (recording from single cells before and after direct application of $\mathrm{TNF} \alpha$ ) would allow detection of frequency changes much more readily than the technique used in this work (cross cell comparisons of TNF $\alpha$-treated and untreated coverslips) because of the very high variability of mEPSC frequency across cells. We also frequently observed a small rundown of mEPSC amplitudes over time during recordings from control cells, and this did not occur in cells treated with TNF $\alpha$ (Beattie et al., 2002, their supplementary material). This may have obscured detecting increases in mEPSC amplitude in the 
A
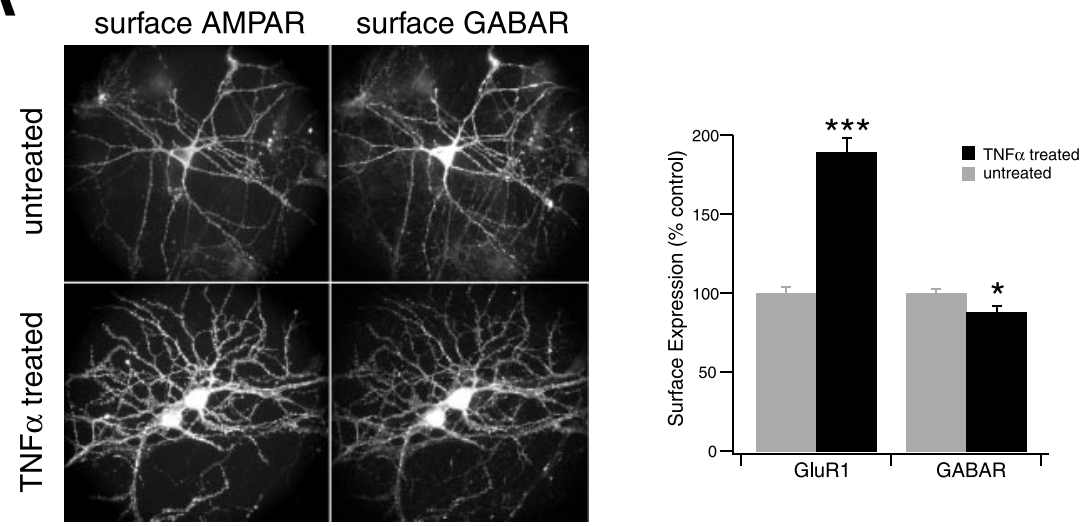

B

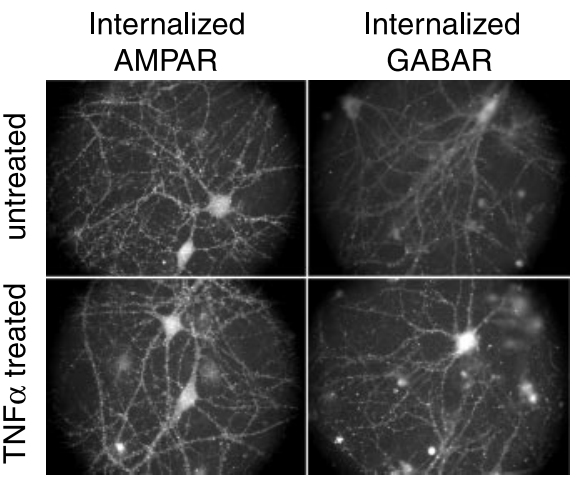

increase in surface expression of AMPARs. However, soluble TNF $\alpha$, which was used for many of our experiments, binds TNFR1 with much higher affinity than TNFR2 (MacEwan, 2002). It is therefore possible that TNFR2 could be capable of initiating the same or a complementary signaling cascade, resulting in an increase in the surface expression of AMPARs. We could not formally rule out this possibility because we do not know whether the TNFR2 agonist used in these experiments achieved maximal activation of TNFR2. However, using a TNFR2 neutralizing antibody, we determined that TNFR2 activation is not necessary for the maintenance of surface AMPARs. Considered together with our other results, this strongly suggests that endogenous TNF $\alpha$ acts solely on TNFR1 to regulate AMPAR surface expression.

Experiments using inhibitors of a variety of protein kinases, as well as COX, suggest that, downstream of the TNFR1 receptor, PI3K activity is required for the increase in AMPAR surface expression. This is perhaps not surprising given that the similar increases in AMPAR surface expression elicited by insulin and glycine treatments also require PI3K activity (Passafaro et al., 2001; Man et al., 2003). However, glycine treatment caused an increase in surface expression of both GluR1 and GluR2 (Lu et al., 2001; Man et al., 2003), although we observed a large increase in surface GluR1 with TNF $\alpha$ but no significant change in surface GluR2. Impordouble labeled for surface GluR1 and the $\beta 2 / 3$ subunit of the $G_{A B A}$ receptors (GABAR). In cells showing a robust increase in GluR1 after TNF $\alpha$ treatment, there was a small but significant decrease in surface expression of GABAR compared with cells from untreated sister cultures. $\boldsymbol{B}$, Sample images and composite data from cells labeled for endocytosed GluR1 or GABAR. TNF $\alpha$ treatment (black bars) increased the endocytosis of GABAR but not GluR1 relative to cells from untreated cultures (gray bars).

previous experiments. In addition, the current method looked at a slightly later time point $(20-40 \mathrm{~min}$ after TNF $\alpha)$ than previously (10-15 min), and mEPSC amplitude changes may occur at a slower rate. Finally, we used bath application of TNF $\alpha$ (identical to what was used for immunocytochemistry), which may simply be a more effective method of application, resulting in greater changes in amplitude.

We addressed the question of whether the effects of TNF $\alpha$ on receptor trafficking and synaptic transmission represent a general feature of most or all cytokines by examining the effects of a number of different proinflammatory and non-inflammatory cytokines on AMPAR surface expression. Our results suggest that TNF $\alpha$ has a unique role in the neuronal regulation of neurotransmitter receptors. IL- $1 \beta$ was less efficacious than TNF $\alpha$ at increasing surface AMPARs, and we found no evidence for the constitutive regulation of AMPARs in culture by IL-1 $\beta$, unlike TNF $\alpha$. Furthermore, other proinflammatory (IL-6) and antiinflammatory (IL-10) cytokines were ineffective at altering the surface expression of AMPARs. These results suggest that TNF $\alpha$ is a member of the subset of cytokines that are used endogenously by the nervous system for the regulation of neurotransmission.

TNF $\alpha$ can activate two distinct receptors, TNFR1 and TNFR2, which couple to distinct but overlapping intracellular signaling pathways (for review, see Rath and Aggarwal, 1999; Baud and Karin, 2001; MacEwan, 2002). Our results suggest that activation of TNFR1 is both necessary and sufficient for the TNF $\alpha$-induced tantly, electrophysiological experiments indicated that this change in the subunit composition of AMPARs also occurred at synapses because HPP-spermine decreased mEPSC amplitude soon after TNF $\alpha$ treatment. These new synaptic AMPARs are likely replaced over time by GluR2-containing receptors, because HPP-spermine had no effect on mEPSCs recorded from control neurons despite the finding that constitutive TNF $\alpha$ release is necessary to maintain normal levels of surface AMPARs. However, even the short-term appearance of a significant population of GluR2-lacking, $\mathrm{Ca}^{2+}$-permeable AMPARs could have important functional implications for synaptic plasticity as well as excitotoxicity (see below). Furthermore, these results suggest that a reserve pool of non-GluR2-containing AMPARs exists near, but not on, the membrane and can be readily trafficked to the surface by TNF $\alpha$ signaling. The rapid, constitutive cycling of AMPARs may then replace GluR2-lacking receptors with GluR2containing ones, returning the GluR2-lacking receptors to the reserve pool. TNF $\alpha$ may also increase the size of the pool of non-GluR2-containing AMPARs, because $24 \mathrm{~h}$ treatment with TNF $\alpha$ has been reported to increase the expression of GluR1, but not other AMPAR subunits, in a neuronal cell line ( $\mathrm{Yu}$ et al., 2002).

A surprising finding was that TNF $\alpha$ causes the endocytosis of $\mathrm{GABA}_{\mathrm{A}}$ receptors and a decrease in inhibitory synaptic strength. The increase in excitatory synaptic transmission combined with the decrease in inhibitory transmission is, to our knowledge, a 
unique feature of TNF $\alpha$ action unlike that caused by other more extensively studied neuromodulators. This change in circuit behavior is, however, similar to the homeostatic mechanisms that appear to come into play when prolonged changes in activity level occur (Turrigiano and Nelson, 2004). Specifically, when circuit activity is pharmacologically reduced, excitatory synapses are strengthened and inhibitory synapses weakened (Turrigiano and Nelson, 2004), at least in part through changes in the synaptic surface expression of AMPARs and $\mathrm{GABA}_{\mathrm{A}}$ receptors (Kilman et al., 2002; Turrigiano and Nelson, 2004). The mediators of this process are unknown. Our data suggest one possible mechanism that may contribute to this homeostatic plasticity. Glia, sensing circuit activity levels possibly through glutamate spillover or extracellular ionic concentrations, might release $\mathrm{TNF} \alpha$ in an inverse relationship with activity levels. As activity falls, TNF $\alpha$ release would be increased, strengthening excitatory synapses but weakening inhibitory ones. In the context of this hypothesis, it is interesting to note that the new AMPARs that appear during homeostatic "synaptic scaling" induced by activity blockade also lack GluR2 (Thiagarajan et al., 2003; Ju et al., 2004).

Independent of whether or not the actions of TNF $\alpha$ reported here play a role in adaptive neural circuit function, the effects of TNF $\alpha$ on AMPAR and $\mathrm{GABA}_{\mathrm{A}}$ receptor trafficking have important implications for the role of $\mathrm{TNF} \alpha$ in neuropathology. The release of TNF $\alpha$ is upregulated by a variety of neuronal insults and disease states (New et al., 1998; Lock et al., 1999; Nagatsu et al., 2000; Perry et al., 2001), and preventing its signaling in vivo can, for example, prevent or reduce neuron loss after cerebral ischemia (Dawson et al., 1996; Barone et al., 1997; Meistrell et al., 1997) and head injury (for review, see Barone et al., 1997; Shohami et al., 1999). The pathological contributions of TNF $\alpha$ to neural injury are likely, at least in part, attributable to its ability to potentiate glutamate excitotoxicity (Gelbard et al., 1993; Chao and Hu, 1994; New et al., 1998; Epstein and Gelbard, 1999; Hermann et al., 2001), which importantly contributes to much of the secondary damage after brain insults (Choi, 1994; Wrathall et al., 1994). The findings presented here, specifically an increase in surface AMPARs, a change in their stoichiometry to make them $\mathrm{Ca}^{2+}$ permeable, and a decrease in inhibition, all will enhance the excitotoxicity that accompanies neuronal insults and some autoimmune and neurodegenerative diseases that may involve TNF $\alpha$ (Epstein and Gelbard, 1999; Weiss and Sensi, 2000). Indeed, a number of neuronal insults, including hypoxia, ischemia, epileptiform activity, and spinal cord contusions, show an increase in non-GluR2-containing AMPARs (Ying et al., 1997; Grossman et al., 1999; Grooms et al., 2000; Sanchez et al., 2001), and increasing the proportion of calcium-permeable AMPARs greatly increases neuronal vulnerability (Feldmeyer et al., 1999; Oguro et al., 1999). Together, these data suggest that dysregulation of the trafficking of a reserve pool of non-GluR2-containing AMPARs could underlie aspects of several neurological disor-
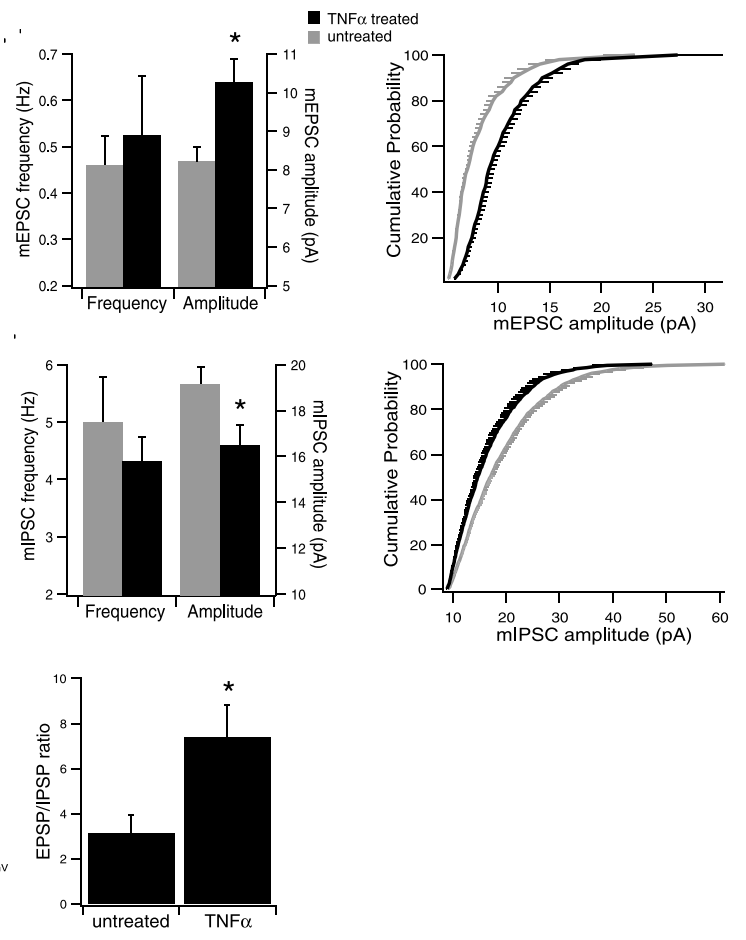

treated

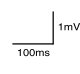

untreated ${ }^{\prime}$ TNF $\alpha^{\prime}$

$\stackrel{20}{m I P S C}$ amplitude $\stackrel{50}{(\mathrm{pA})}$

Figure 7. TNF $\alpha$ increases the ratio of excitatory to inhibitory synaptic transmission in acute hippocampal slices. $\boldsymbol{A}$, TNF $\alpha$ increases mEPSC amplitude. Left, Representative average mEPSCs from cells treated with TNF $\alpha$ and untreated slices. Middle, Composite data of average mEPSC frequency and amplitude of cells from untreated (gray; $n=10$ ) and TNF $\alpha$-treated (black; $n=12$ ) slices. Right,

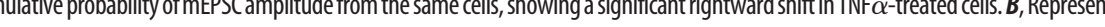
postsynaptic potentials of cells from TNF $\alpha$-treated slices and untreated slices from the same animal. TNF $\alpha$-treated cells $(n=11)$ had a significantly higher ratio of the EPSP to IPSP amplitude than untreated cells $(n=10)$.

ders. Similarly, the effects of TNF $\alpha$ could contribute to the modification of circuit behavior that underlies the hyperalgesia after peripheral nerve damage, a neuropathological state that involves glia-released cytokines, including TNF $\alpha$ (Watkins et al., 2001; Milligan et al., 2003). Additional work will be necessary to determine whether pharmacological manipulations can be developed that will interfere with the pathological consequences of increased TNF $\alpha$ signaling while not significantly inhibiting its potential role in adaptive neural circuit reorganization.

\section{References}

Barone FC, Arvin B, White RF, Miller A, Webb CL, Willette RN, Lysko PG, Feuerstein GZ (1997) Tumor necrosis factor-alpha. A mediator of focal ischemic brain injury. Stroke 28:1233-1244.

Baud V, Karin M (2001) Signal transduction by tumor necrosis factor and its relatives. Trends Cell Biol 11:372-377.

Beattie EC, Carroll RC, Yu X, Morishita W, Yasuda H, von Zastrow M, Malenka RC (2000) Regulation of AMPA receptor endocytosis by a signaling mechanism shared with LTD. Nat Neurosci 3:1291-1300.

Beattie EC, Stellwagen D, Morishita W, Bresnahan JC, Ha BK, Von Zastrow M, Beattie MS, Malenka RC (2002) Control of synaptic strength by glial TNFalpha. Science 295:2282-2285.

Bezzi P, Domercq M, Brambilla L, Galli R, Schols D, De Clercq E, Vescovi A, Bagetta G, Kollias G, Meldolesi J, Volterra A (2001) CXCR4-activated astrocyte glutamate release via TNFalpha: amplification by microglia triggers neurotoxicity. Nat Neurosci 4:702-710.

Chao CC, Hu S (1994) Tumor necrosis factor-alpha potentiates glutamate neurotoxicity in human fetal brain cell cultures. Dev Neurosci 16:172-179.

Choi DW (1994) Glutamate receptors and the induction of excitotoxic neuronal death. Prog Brain Res 100:47-51.

Dawson DA, Martin D, Hallenbeck JM (1996) Inhibition of tumor necrosis 
factor-alpha reduces focal cerebral ischemic injury in the spontaneously hypertensive rat. Neurosci Lett 218:41-44.

Diem R, Meyer R, Weishaupt JH, Bahr M (2001) Reduction of potassium currents and phosphatidylinositol 3-kinase-dependent AKT phosphorylation by tumor necrosis factor- $\alpha$ rescues axotomized retinal ganglion cells from retrograde cell death in vivo. J Neurosci 21:2058-2066.

Dingledine R, Borges K, Bowie D, Traynelis SF (1999) The glutamate receptor ion channels. Pharmacol Rev 51:7-61.

Ehlers MD (2000) Reinsertion or degradation of AMPA receptors determined by activity-dependent endocytic sorting. Neuron 28:511-525.

Emch GS, Hermann GE, Rogers RC (2000) TNF-alpha activates solitary nucleus neurons responsive to gastric distension. Am J Physiol Gastrointest Liver Physiol 279:G582-G586.

Epstein LG, Gelbard HA (1999) HIV-1-induced neuronal injury in the developing brain. J Leukoc Biol 65:453-457.

Feldmeyer D, Kask K, Brusa R, Kornau HC, Kolhekar R, Rozov A, Burnashev N, Jensen V, Hvalby O, Sprengel R, Seeburg PH (1999) Neurological dysfunctions in mice expressing different levels of the Q/R site-unedited AMPAR subunit GluR-B. Nat Neurosci 2:57-64.

Gelbard HA, Dzenko KA, DiLoreto D, del Cerro C, del Cerro M, Epstein LG (1993) Neurotoxic effects of tumor necrosis factor alpha in primary human neuronal cultures are mediated by activation of the glutamate AMPA receptor subtype: implications for AIDS neuropathogenesis. Dev Neurosci $15: 417-422$.

Golan H, Levav T, Mendelsohn A, Huleihel M (2004) Involvement of tumor necrosis factor alpha in hippocampal development and function. Cereb Cortex 14:97-105.

Goslin K, Asmussen H, Banker G (1998) Rat hippocampal neurons in lowdensity culture. In: Culturing nerve cells (Goslin K, Banker G, eds), pp 339-370. Cambridge, MA: MIT.

Grassi F, Mileo AM, Monaco L, Punturieri A, Santoni A, Eusebi F (1994) TNF-alpha increases the frequency of spontaneous miniature synaptic currents in cultured rat hippocampal neurons. Brain Res 659:226-230.

Grooms SY, Opitz T, Bennett MV, Zukin RS (2000) Status epilepticus decreases glutamate receptor $2 \mathrm{mRNA}$ and protein expression in hippocampal pyramidal cells before neuronal death. Proc Natl Acad Sci USA 97:3631-3636.

Grossman SD, Wolfe BB, Yasuda RP, Wrathall JR (1999) Alterations in AMPA receptor subunit expression after experimental spinal cord contusion injury. J Neurosci 19:5711-5720.

Hermann GE, Rogers RC, Bresnahan JC, Beattie MS (2001) Tumor necrosis factor-alpha induces cFOS and strongly potentiates glutamate-mediated cell death in the rat spinal cord. Neurobiol Dis 8:590-599.

Ju W, Morishita W, Tsui J, Gaietta G, Deerinck TJ, Adams SR, Garner CC, Tsien RY, Ellisman MH, Malenka RC (2004) Activity-dependent regulation of dendritic synthesis and trafficking of AMPA receptors. Nat Neurosci 7:244-253.

Kilman V, van Rossum MC, Turrigiano GG (2002) Activity deprivation reduces miniature IPSC amplitude by decreasing the number of postsynaptic $\mathrm{GABA}_{\mathrm{A}}$ receptors clustered at neocortical synapses. J Neurosci 22:1328-1337.

Kim KA, von Zastrow M (2003) Neurotrophin-regulated sorting of opioid receptors in the biosynthetic pathway of neurosecretory cells. J Neurosci 23:2075-2085.

Le D, Das S, Wang YF, Yoshizawa T, Sasaki YF, Takasu M, Nemes A, Mendelsohn M, Dikkes P, Lipton SA, Nakanishi N (1997) Enhanced neuronal death from focal ischemia in AMPA-receptor transgenic mice. Brain Res Mol Brain Res 52:235-241.

Lock C, Oksenberg J, Steinman L (1999) The role of TNFalpha and lymphotoxin in demyelinating disease. Ann Rheum Dis 58 [Suppl 1]:I121-I128.

Lu W, Man H, Ju W, Trimble WS, MacDonald JF, Wang YT (2001) Activation of synaptic NMDA receptors induces membrane insertion of new AMPA receptors and LTP in cultured hippocampal neurons. Neuron 29:243-254.

Luscher C, Xia H, Beattie EC, Carroll RC, von Zastrow M, Malenka RC, Nicoll RA (1999) Role of AMPA receptor cycling in synaptic transmission and plasticity. Neuron 24:649-658.

MacEwan DJ (2002) TNF ligands and receptors-a matter of life and death. Br J Pharmacol 135:855-875.

Mainen ZF, Jia Z, Roder J, Malinow R (1998) Use-dependent AMPA receptor block in mice lacking GluR2 suggests postsynaptic site for LTP expression. Nat Neurosci 1:579-586.
Malinow R, Malenka RC (2002) AMPA receptor trafficking and synaptic plasticity. Annu Rev Neurosci 25:103-126.

Man HY, Wang Q, Lu WY, Ju W, Ahmadian G, Liu L, D'Souza S, Wong TP, Taghibiglou C, Lu J, Becker LE, Pei L, Liu F, Wymann MP, MacDonald JF, Wang YT (2003) Activation of PI3-kinase is required for AMPA receptor insertion during LTP of mEPSCs in cultured hippocampal neurons. Neuron 38:611-624.

Meistrell III ME, Botchkina GI, Wang H, Di Santo E, Cockroft KM, Bloom O, Vishnubhakat JM, Ghezzi P, Tracey KJ (1997) Tumor necrosis factor is a brain damaging cytokine in cerebral ischemia. Shock 8:341-348.

Milligan ED, Twining C, Chacur M, Biedenkapp J, O’Connor K, Poole S, Tracey K, Martin D, Maier SF, Watkins LR (2003) Spinal glia and proinflammatory cytokines mediate mirror-image neuropathic pain in rats. J Neurosci 23:1026-1040.

Morganti-Kossmann MC, Rancan M, Stahel PF, Kossmann T (2002) Inflammatory response in acute traumatic brain injury: a double-edged sword. Curr Opin Crit Care 8:101-105.

Nagatsu T, Mogi M, Ichinose H, Togari A (2000) Cytokines in Parkinson's disease. J Neural Transm Suppl 58:143-151.

Neumann H, Schweigreiter R, Yamashita T, Rosenkranz K, Wekerle H, Barde YA (2002) Tumor necrosis factor inhibits neurite outgrowth and branching of hippocampal neurons by a Rho-dependent mechanism. J Neurosci 22:854-862.

New DR, Maggirwar SB, Epstein LG, Dewhurst S, Gelbard HA (1998) HIV-1 Tat induces neuronal death via tumor necrosis factor-alpha and activation of non- $N$-methyl-D-aspartate receptors by a NFkappaBindependent mechanism. J Biol Chem 273:17852-17858.

Oguro K, Oguro N, Kojima T, Grooms SY, Calderone A, Zheng X, Bennett MV, Zukin RS (1999) Knockdown of AMPA receptor GluR2 expression causes delayed neurodegeneration and increases damage by sublethal ischemia in hippocampal CA1 and CA3 neurons. J Neurosci 19:9218-9227.

Pan W, Zadina JE, Harlan RE, Weber JT, Banks WA, Kastin AJ (1997) Tumor necrosis factor-alpha: a neuromodulator in the CNS. Neurosci Biobehav Rev 21:603-613.

Passafaro M, Piech V, Sheng M (2001) Subunit-specific temporal and spatial patterns of AMPA receptor exocytosis in hippocampal neurons. Nat Neurosci 4:917-926.

Perry RT, Collins JS, Wiener H, Acton R, Go RC (2001) The role of TNF and its receptors in Alzheimer's disease. Neurobiol Aging 22:873-883.

Perry SW, Dewhurst S, Bellizzi MJ, Gelbard HA (2002) Tumor necrosis factor-alpha in normal and diseased brain: conflicting effects via intraneuronal receptor crosstalk? J Neurovirol 8:611-624.

Persohn E, Malherbe P, Richards JG (1992) Comparative molecular neuroanatomy of cloned GABAA receptor subunits in the rat CNS. J Comp Neurol 326:193-216.

Rath PC, Aggarwal BB (1999) TNF-induced signaling in apoptosis. J Clin Immunol 19:350-364.

Richards JG, Schoch P, Haring P, Takacs B, Mohler H (1987) Resolving $\mathrm{GABA}_{\mathrm{A}} /$ benzodiazepine receptors: cellular and subcellular localization in the CNS with monoclonal antibodies. J Neurosci 7:1866-1886.

Sanchez RM, Koh S, Rio C, Wang C, Lamperti ED, Sharma D, Corfas G, Jensen FE (2001) Decreased glutamate receptor 2 expression and enhanced epileptogenesis in immature rat hippocampus after perinatal hypoxia-induced seizures. J Neurosci 21:8154-8163.

Shohami E, Ginis I, Hallenbeck JM (1999) Dual role of tumor necrosis factor alpha in brain injury. Cytokine Growth Factor Rev 10:119-130.

Sperk G, Schwarzer C, Tsunashima K, Fuchs K, Sieghart W (1997) GABA(A) receptor subunits in the rat hippocampus I: immunocytochemical distribution of 13 subunits. Neuroscience 80:987-1000.

Stoll G, Jander S, Schroeter M (2002) Detrimental and beneficial effects of injury-induced inflammation and cytokine expression in the nervous system. Adv Exp Med Biol 513:87-113.

Szelenyi J (2001) Cytokines and the central nervous system. Brain Res Bull 54:329-338.

Tancredi V, D’Arcangelo G, Grassi F, Tarroni P, Palmieri G, Santoni A, Eusebi F (1992) Tumor necrosis factor alters synaptic transmission in rat hippocampal slices. Neurosci Lett 146:176-178.

Tartaglia LA, Weber RF, Figari IS, Reynolds C, Palladino Jr MA, Goeddel DV (1991) The two different receptors for tumor necrosis factor mediate distinct cellular responses. Proc Natl Acad Sci USA 88:9292-9296.

Thiagarajan TC, Lindskog M, Tsien RW (2003) Inactivity in hippocampal 
neurons leads to increased GluR1 transmission via $\beta$ CaMKII. Soc Neurosci Abstr 29:10.1.

Tsao PI, von Zastrow M (2000) Type-specific sorting of G protein-coupled receptors after endocytosis. J Biol Chem 275:11130-11140.

Turrigiano GG, Nelson SB (2004) Homeostatic plasticity in the developing nervous system. Nat Rev Neurosci 5:97-107.

Vitkovic L, Konsman JP, Bockaert J, Dantzer R, Homburger V, Jacque C (2000) Cytokine signals propagate through the brain. Mol Psychiatry 5:604-615.

Washburn MS, Numberger M, Zhang S, Dingledine R (1997) Differential dependence on GluR2 expression of three characteristic features of AMPA receptors. J Neurosci 17:9393-9406.

Watkins LR, Milligan ED, Maier SF (2001) Glial activation: a driving force for pathological pain. Trends Neurosci 24:450-455.

Weiss JH, Sensi SL (2000) $\mathrm{Ca}^{2+}-\mathrm{Zn}^{2+}$ permeable AMPA or kainate receptors: possible key factors in selective neurodegeneration. Trends Neurosci 23:365-371.

Wenthold RJ, Petralia RS, Blahos J, II, Niedzielski AS. (1996) Evidence for multiple AMPA receptor complexes in hippocampal CA1/CA2 neurons. J Neurosci 16:1982-1989.

Wrathall JR, Choiniere D, Teng YD (1994) Dose-dependent reduction of tissue loss and functional impairment after spinal cord trauma with the AMPA/kainate antagonist NBQX. J Neurosci 14:6598-6607.

Yang L, Lindholm K, Konishi Y, Li R, Shen Y (2002) Target depletion of distinct tumor necrosis factor receptor subtypes reveals hippocampal neuron death and survival through different signal transduction pathways. J Neurosci 22:3025-3032.

Ying HS, Weishaupt JH, Grabb M, Canzoniero LM, Sensi SL, Sheline CT, Monyer H, Choi DW (1997) Sublethal oxygen-glucose deprivation alters hippocampal neuronal AMPA receptor expression and vulnerability to kainate-induced death. J Neurosci 17:9536-9544.

Yu Z, Cheng G, Wen X, Wu GD, Lee WT, Pleasure D (2002) Tumor necrosis factor alpha increases neuronal vulnerability to excitotoxic necrosis by inducing expression of the AMPA-glutamate receptor subunit GluR1 via an acid sphingomyelinase- and NF-kappaB-dependent mechanism. Neurobiol Dis 11:199-213. 